\title{
IMPLEMENTASI CYBER MARKETING DALAM MENDUKUNG PENDAFTARAN ONLINE MAHASISWA BARU PADA PERGURUAN TINGGI (STUDI KASUS : UNIVERSITAS RAHARJA)
}

\author{
Sudaryono ${ }^{1}$, Karunia Suci Lestari ${ }^{2}$, Yunita Wulansari ${ }^{3}$ \\ ${ }_{1,2,3}$ Program Studi Magister Teknik Informatika Universitas Raharja \\ ${ }^{1}$ sudaryono@raharja.info ${ }^{2}$ suci@raharja.info, ${ }^{3}$ yunita@,raharja.info
}

\begin{abstract}
Abstraksi
Peranan digital dalam dunia pemasaran sangatlah penting dalam strategi pencapaian target mendapatkan konsumen baru. Sehingga tak heran banyak perguruan tinggi yang beralih ke digital marketing dalam strategi pemasaran untuk mendapatkan calon mahasiswa baru, sehingga Universitas Raharja perlu mengikuti trend pemasaran saat ini menggunakan digital marketing seperti website Penerimaan Mahasiswa Baru dalam menyampaikan informasi dan melakukan promosi kampus untuk mendukung pendaftaran online mahasiswa baru. Cyber Marketing/ Internet Marketing menjadi sangat diperlukan dalam segmen e-commerce, cyber marketing merupakan arah teknik untuk menarik konsumen potensial untuk membeli produk/jasa yang ditawarkan melalui website, email atau sosial media. Internet marketing adalah segala upaya dilakukan untuk melakukan pemasaran suatu produk atau jasa melalui atau menggunakan media elektronik dan internet. Sehingga dengan adanya website pmb.raharja.ac.id ini calon mahasiswa baru tidak perlu datang langsung ke kampus untuk melakukan pendaftaran calon mahasiswa baru. Manfaat dari penelitian ini memudahkan para calon mahasiswa baru yang tidak mempunyai waktu atau jarak tempuh yang jauh untuk menjangkau kampus untuk melakukan registrasi mahasiswa. Metode yang digunakan dalam penelitian ini adalah pengumpulan data, analisis data menggunakan metode analisis PIECES, metode pengembangan sistem menggunakan SDLC, metode studi pustaka, serta metode perancangan menggunakan UML meliputi use case diagram, class diagram dan activity diagram. Melalui website ini, diharapkan pendaftaran online mahasiswa baru dapat meningkatkan calon Pribadi Raharja di Universitas Raharja.
\end{abstract}

Kata Kunci : Cybermarketing, Pendaftaran, Website, Mahasiswa Baru

\begin{abstract}
The role of digital in the world of marketing is very important in the strategy of achieving the target of gaining new consumers. So no wonder many universities are turning to digital marketing in marketing strategies to get new students, so Raharja University needs to follow the current marketing trends using digital marketing such as the New Student Admissions website in conveying information and conducting campus promotions to support online registration of new students. Cyber Marketing / Internet Marketing becomes very necessary in the e-commerce segment, cyber marketing is a technical direction to attract potential consumers to buy products / services offered through websites, email or social media. Internet marketing is any effort made to do marketing of a product or service through or using electronic media and the internet. So with this website pmb.raharja.ac.id prospective new students do not need to come directly to the campus to register new students. The benefits of this research make it easier for prospective new students who do not have the time or long distance to reach the campus to register students. The methods used in this research are data collection, data analysis using PIECES analysis method, system development method using SDLC, library study method, and design method using UML including use case diagram, class diagram and activity diagram. Through this website, it is expected that the online registration of new students can increase the candidates of Personal Raharja at Raharja University.
\end{abstract}

Keyword : Cybermarketing, Registration, Website, New Students 


\section{Pendahuluan}

Peranan Digital dalam dunia pemasaran sangatlah penting dalam strategi untuk mendapatkan konsumen baru, seperti : memberikan cara baru dan kemudahan baik dalam hal pemasaran maupun kemudahan dalam berkomunikasi antar pemasar dan konsumen sehingga pemasar lebih mudah dan dapat memahami seperti apa yang sesuai dengan kebutuhan dan keinginan konsumen yang dikenal dengan istilah Internet Marketing, Digital Marketing atau Cyber Marketing. Pemasaran digital melibatkan teknologi digital seperti web, email, database, seluler/ nirkabel, sosial media maupun iklan digital Televisi. Adapun manfaat dari pemasaran digital seperti biaya lebih rendah, terukur, personalisasi, identifikasi, pengembangan merk, eksposur atau jangkauan global, viral, tidak mengganggu, keterbukaan dan memuaskan (Rumondang et al, 2020). Dengan kata lain Cyber Marketing/ Internet Marketing merupakan penggabungan antara teknologi internet dan pemasaran atau periklanan dengan menggunakan internet sebagai media untuk mengirimkan berbagai informasi maupun pesan yang bersifat promosi kepada calon konsumen secara langsung (online) dengan tujuan untuk membangun relasi dengan calon konsumen dan tentunya untuk menghasilkan profit perusahaan.

Dalam dunia pendidikan Cyber Marketing ini sangatlah membantu calon mahasiswa/i seperti Siswa/i SMA, SMK, MA maupun MAK dalam menentukan Perguruan tinggi maupun Universitas untuk menempuh pendidikan lanjut mereka. Berdasarkan Perkembangan Jumlah Lembaga Perguruan Tinggi (PT) tiap Provinsi Jumlah Perguruan Tinggi di Indonesia terdiri dari 122 Perguruan Tinggi Negeri (PTN) dan 3.171 Perguruan Tinggi Swasta (PTS). Perguruan Tinggi tersebut terdiri dari Universitas, Perguruan Tinggi, Sekolah Tinggi, Institusi serta Politeknik. Selain nama kampus yang ternama, calon mahasiswa perlu mengetahui fasilitas kampus, informasi Program Studi serta informasi tentang biaya kuliah mereka terlebih dahulu sebelum mengambil keputusan untuk melanjutkan pendidikan dimana. Sehingga calon mahasiswa perlu datang langsung ke kampus untuk mengetahui informasi tentang fasilitas, Program Studi serta informasi biaya kuliah. Banyak Perguruan Tinggi yang menggunakan Digital Marketing seperti website guna memudahkan para calon mahasiswa baru (CMB) mengetahui fasilitas, informasi Program Studi dan info biaya kuliah, Perguruan Tinggi lainnya pun mulai menggunakan website guna memperluas strategi pemasaran mereka mendapatkan calon mahasiswa baru. Sangat memungkinkan terjadinya perang strategi pemasaran Cyber Marketing ini dalam mendapatkan calon mahasiswa/i baru, baik secara kuantitas maupun kualitas. Setiap perguruan tinggi berupaya memanfaatkan Cyber Marketing ini untuk mendapatkan CMB sebanyak mungkin dengan kualitas yang baik, begitupun Universitas Raharja.

Universitas Raharja merupakan salah satu perguruan tinggi swasta yang berada di tengah kota Tangerang tepatnya di Jalan Sudirman No. 40 Modern Cikokol - Tangerang Banten 15117. Penerimaan Calon Mahasiswa Baru di perguruan tinggi merupakan salah satu faktor kondisi sehat jika perguruan tinggi memiliki kinerja penerimaan calon mahasiswa baru (CMB) yang baik yang tidak hanya dalam satu periode tetapi selalu meningkat setiap tahunnya. Cakupan Sekolah target sosialisasi Universitas Raharja meliputi Kota Tangerang, Kabupaten Tangerang, Kota Tangerang Selatan, dan wilayah sekitar Jakarta Barat. Untuk informasi mengenai Program Studi dan Fasilitas Kampus tercetak dalam bentuk brosur, spanduk yang diberikan dan dibagikan ke sekolah-sekolah saat melakukan sosialisasi; sedangkan informasi mengenai informasi biaya kuliah serta pendaftaran CMB harus datang langsung ke kampus untuk mengetahui rincian biaya kuliah dan registrasi calon mahasiswa baru. Keterbatasan tenaga waktu dan biaya calon 
mahasiswa menjangkau kampus dari tempat tinggal mereka yang jauh, membuat CMB kesulitan untuk datang langsung ke kampus menyempatkan waktu bertanya langsung pada staff penerimaan CMB mengenai fasilitas dan informasi tentang biaya kuliah ataupun langsung melakukan pendaftaran sebagai mahasiswa baru dan sistem sebelumnya yang harus menunggu kode akses selama 2x24 jam. Sehingga dibutuhkan pemasaran dalam bentuk teknologi (Cyber Marketing/ Digital Marketing) berupa website untuk mengetahui informasi Program Studi, fasilitas, info biaya kuliah serta pendaftaran online untuk mempermudah CMB untuk melakukan pendaftaran menjadi bagian Pribadi Raharja secara online, dengan cara mengaksesnya melalui website di pmb.raharja.ac.id.

Situs web itu sendiri dapat memberikan berbagai manfaat, seperti: 1) Menjadi media promosi yang siap diakses kapan saja, sehingga Anda dapat menanggapi permintaan dari konsumen selama 24 jam; 2) Memberikan informasi yang valid kepada pelanggan yang ingin mengetahui tentang produk / layanan; dan 3) Lebih menghemat biaya pemasaran dan efisien (Muharam, et al, 2020). Penggunaan platform digital dalam dunia bisnis tidak asing lagi, karena penggunaan yang memiliki beberapa keuntungan diantaranya: 1) sebagai media yang menjadi gerbang informasi. 2) informasi yang memudahkan calon konsumen 3) memberikan banyak waktu kepada calon konsumen untuk mempelajari produk/jasa yang ditawarkan. 4) akses yang tidak pernah tutup. 5) tidak terhalang jarak. 6) beragamnya pilihan media digital. 7) Biaya digital marketing yang efisien. Namun, dari beberapa keuntungan di atas digital marketing juga memiliki beberapa kekurangan diantaranya: 1) ketergantungan pada teknologi 2) adanya Isu terhadap keamanan dan privasi 3) Teknologi yang terus berkembang menambah biaya pemeliharaan 4) pemerataan yang belum merata khususnya di Indonesia 5) Transparansi Harga 6) Global competition (Suib, et al, 2020).

\section{Metode Penelitian}

\subsection{Teknik Pengumpulan Data}

Untuk merancang situs web pendaftaran siswa baru, perlu mengambil sejumlah sumber yang digunakan dalam membuat situs web PMB termasuk data utama yang diperoleh dari responden penelitian. Data primer diperoleh dari literatur sebagai kerangka kerja dalam desain sistem dan pembuatan database, survei di mana data diperoleh dari wawancara dalam bentuk informasi yang nantinya akan berfungsi sebagai referensi untuk apa yang perlu ditampilkan dalam sistem informasi berbasis web dan pengamatan langsung untuk mempelajari sistem pendaftaran yang saat ini berjalan di perguruan tinggi. . Untuk data sekunder yang diperoleh dalam desain berupa data yang diperoleh dari database penerimaan mahasiswa baru di sebuah perguruan tinggi.

\subsection{Teknik Analisis Data}

Analisis awal digunakan untuk mempelajari sistem pendaftaran saat ini, laporan pendaftaran, dan masalah yang dihadapi oleh Perguruan Tinggi. Metode analisis sistem yang digunakan adalah metode analisis PIECES, yaitu analisis menggunakan Performance, Information, Economy, Control, Efficiency, and Service (James Wetherbe, 2012). Hasil analisis pendaftaran online pada Universitas Raharja sebagai berikut : 
Tabel 1. Analisis PIECES

\begin{tabular}{|c|c|c|}
\hline Kerangka PIECES & Sistem Lama & Sistem Baru \\
\hline Performance (Kinerja) & $\begin{array}{l}\text { Memakan banyak tenaga kerja } \\
\text { untuk mendata jika terjadinya } \\
\text { lonjakan kedatangan calon } \\
\text { mahasiswa baru untuk } \\
\text { mengetahui informasi Program } \\
\text { Studi, fasilitas, info biaya serta } \\
\text { pendaftaran calon mahasiswa } \\
\text { baru sehingga perlu antri dan } \\
\text { pencetakan berkas formulir } \\
\text { pendaftaran. }\end{array}$ & $\begin{array}{l}\text { Pendaftaran menjadi lebih } \\
\text { mudah, calon mahasiswa tidak } \\
\text { perlu datang ke kampus untuk } \\
\text { mengetahui informasi } \\
\text { mengenai Program Studi, } \\
\text { fasilitas, info biaya kuliah serta } \\
\text { mengisi formulir pendaftaran }\end{array}$ \\
\hline Information (Informasi) & $\begin{array}{l}\text { Informasi Program Studi, } \\
\text { Fasilitas berupa brosur dan } \\
\text { sedangkan untuk mengetahui } \\
\text { info biaya kuliah serta } \\
\text { melakukan pendaftaran } \\
\text { mahasiswa baru harus datang } \\
\text { langsung ke kampus. }\end{array}$ & $\begin{array}{l}\text { Data informasi mengenai } \\
\text { Program Studi, Fasilitas, Info } \\
\text { Biaya Kuliah serta pendaftaran } \\
\text { mahasiswa baru disajikan } \\
\text { secara real time, kapanpun } \\
\text { dimanapun dan dapat diakses } \\
\text { secara online. }\end{array}$ \\
\hline Economic (Ekonomi) & $\begin{array}{l}\text { Biaya yang dikeluarkan untuk } \\
\text { pencetakan brosur, spanduk, } \\
\text { informasi biaya kuliah serta } \\
\text { formulir pendaftaran relatif } \\
\text { tinggi }\end{array}$ & $\begin{array}{l}\text { Biaya yang dikeluarkan relatif } \\
\text { rendah karena informasi yang } \\
\text { diinginkan CMB tidak perlu } \\
\text { dicetak karena dapat diakses } \\
\text { secara daring (online) }\end{array}$ \\
\hline Control (Kontrol) & $\begin{array}{l}\text { Sulit mengumpulkan bukti } \\
\text { pembayaran atau pengecekan } \\
\text { bukti pembayaran pendaftaran } \\
\text { di cek secara manual }\end{array}$ & $\begin{array}{l}\text { Semua data bukti transaksi } \\
\text { secara otomatis terdata dalam } \\
\text { satu database pendaftaran } \\
\text { online. }\end{array}$ \\
\hline Efficiency (Efisiensi) & $\begin{array}{l}\text { Perlu merekap data secara } \\
\text { manual untuk mengetahui } \\
\text { jumlah calon mahasiswa yang } \\
\text { registrasi sampai yang telah } \\
\text { bayar registrasi pendaftaran }\end{array}$ & $\begin{array}{l}\text { Seluruh data calon mahasiswa } \\
\text { yang registrasi sampai yang } \\
\text { telah bayar registrasi } \\
\text { pendaftaran online terdata } \\
\text { secara otomatis oleh sistem }\end{array}$ \\
\hline Services (Pelayanan) & $\begin{array}{l}\text { Masih sulit menjangkau calon } \\
\text { mahasiswa yang terbatas waktu } \\
\text { dan tempat untuk datang } \\
\text { langsung ke kampus melakukan } \\
\text { pendaftaran }\end{array}$ & $\begin{array}{l}\text { Akses bisa dilakukan dimana } \\
\text { saja dan kapanpun saja, } \\
\text { sehingga calon mahasiswa } \\
\text { tidak perlu repot untuk datang } \\
\text { langsung ke kampus. }\end{array}$ \\
\hline
\end{tabular}

\subsection{Strategi Pengembangan Sistem}

Metode yang digunakan dalam desain sistem informasi adalah $S D L C$ (System Development Life Cycle), yang merupakan pendekatan melalui beberapa tahap mulai dari menganalisis dan merancang sistem di mana sistem dikembangkan melalui penggunaan siklus aktivitas penganalisa hingga tahap implementasi dan pemeliharaan. 


\subsection{Studi Pustaka (Literature Review)}

Berdasarkan penelitian Terinspirasi penelitian dari (Legawa, et al, 2017) melakukan penelitian dengan judul "Merancang Data Mart Perancangan Dashboard Penerimaan Mahasiswa Baru Universitas Muhammadiyah Tangerang". Sistem ini bertujuan untuk merancang data mart yang hasilnya ditampilkan di dasbor penerimaan siswa baru. Dimana data tersebut dapat memberikan laporan yang detail, aktual, terintegrasi, otomatis, dan mudah diakses kepada kepala bagian Penerimaan Mahasiswa Baru Universitas Muhammadiyah Tangerang yang dibuat menggunakan Ms. Access dan Excel Powerpivot.

Penelitian Muharam dan Andhika Giri Persada (2020)membuat penelitian dengan judul "Implementasi Penggunaan Website Sebagai Media Informasi dan Media Pemasaran Hasil Pertanian dan Peternakan Desa Sumberejo". Membuat website, e-commerce, dan media sosial Produk Pertanian dan Peternakan di Desa Sumberejo sebagai media informasi dan pemasaran untuk produk petani dan peternak. Penerapan dan implementasi teknologi yang diusulkan adalah penggunaan website menggunakan platform dari wordpress sebagai media informasi dan pemasaran hasil pertanian dan peternakan di Desa Sumberejo. Platform dari wordpress dipilih karena mudah digunakan, dikelola, dipelajari, dan fleksibel (dapat diakses menggunakan perangkat atau komputer). Selain itu, wordpress juga sangat mudah dalam hal pemeliharaan Muharam et al, (2020).

Penelitian yang dilakukan Muslih (2015) dengan judul "Pengembangan Emarketing Penerimaan Mahasiswa Baru (PMB) Dengan Menggunakan Metode Service Oriented Architecture (SOA) : Studi Kasus Pada STT Nusa Putra Sukabumi". Penelitian ini menjelaskan perkembangan E-Marketing PMB divisi PMB di STT Nusa Putra Sukabumi yang lincah dan dapat digunakan kembali berdasarkan SOA dengan penerapan layanan web tersebut. Hasil penelitian ini membuktikan bahwa Pengembangan Sistem E-Marketing PMB dengan Arsitektur $S O A$ di Divisi PMB dapat memberikan kemudahan kepada pengguna sistem, dalam hal ini Divisi PMB dan sekolah yang merupakan mitra STT Nusa Putra Sukabumi, hasil analisis sistem yang sedang berjalan kemudian divisualisasikan dan didokumentasikan dengan Unified Modeling Language (UML) dengan membuat Use Case Diagram, Activity Diagram, Sequence Diagram dan Class Diagram (Muslih, 2015).

\subsection{Desain Perancangan}

Pada tahap berikut setelah analisis awal adalah perancangan model logika untuk menyelesaikan masalah-masalah pada proses pendaftaran mahasiswa baru, penggunaan model UML (Unified Modelling Language) merupakan bagian dari perancangan sistem. Perancangan sistem meliputi Use Case Diagram, Class Diagram dan Activity Diagram.

\section{Hasil Dan Pembahasan}

\subsection{Rancangan Sistem Pendaftaran Online}

Pada metode perancangan, Penulis menggunakan pendekatan Unified Modeling Language (UML) sebagai salah satu alat bantu untuk memodelkan secara visual yang dapat digunakan dalam bahasa pemrograman yang berorientasi objek. $U M L$ terdiri dari beberapa diagram yang saling berkaitan, antara lain Usecase Diagram, Activity Diagram, Sequence Diagram dan Class Diagram. 


\subsubsection{Use Case Diagram Pendaftaran Online}

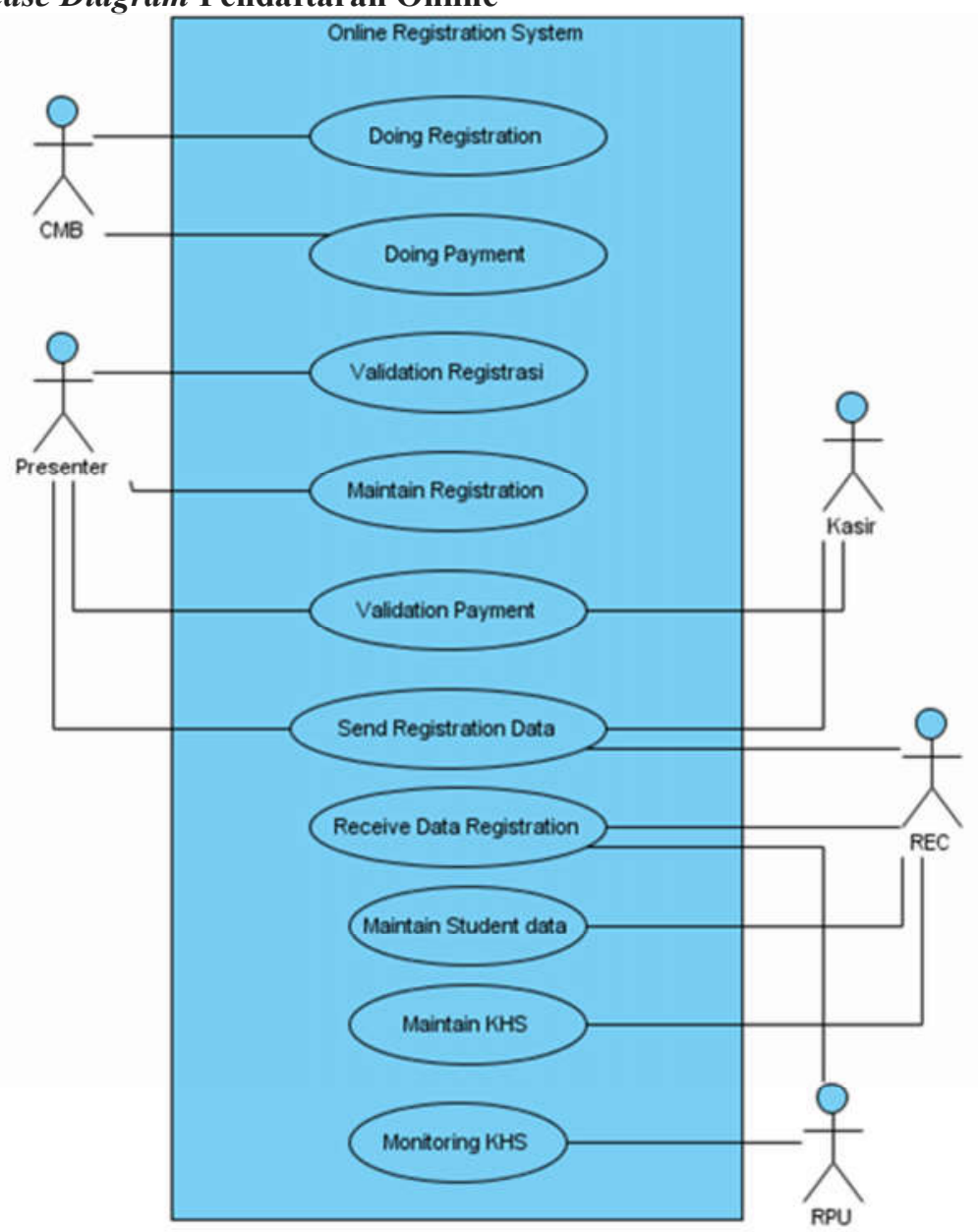

Gambar 1. Use Case Diagram Pendaftaran Online

Berdasarkan gambar use case diagram di atas terdapat:

1. Terdapat 1 sistem yang mencakup kegiatan proses pendaftaran online.

2. Terdapat 5 Actor dalam kegiatan yaitu: CMB (Calon Mahasiswa Baru), Presenter, Kasir, REC dan RPU

3. Terdapat 10 Use Case yaitu: Doing Registration, Doing Payment,Validation Payment, Send Registration Data, Receive data registration, maintain student data, maintan KHS, monitoring KHS 


\subsubsection{Activity Diagram Pendaftaran Online}

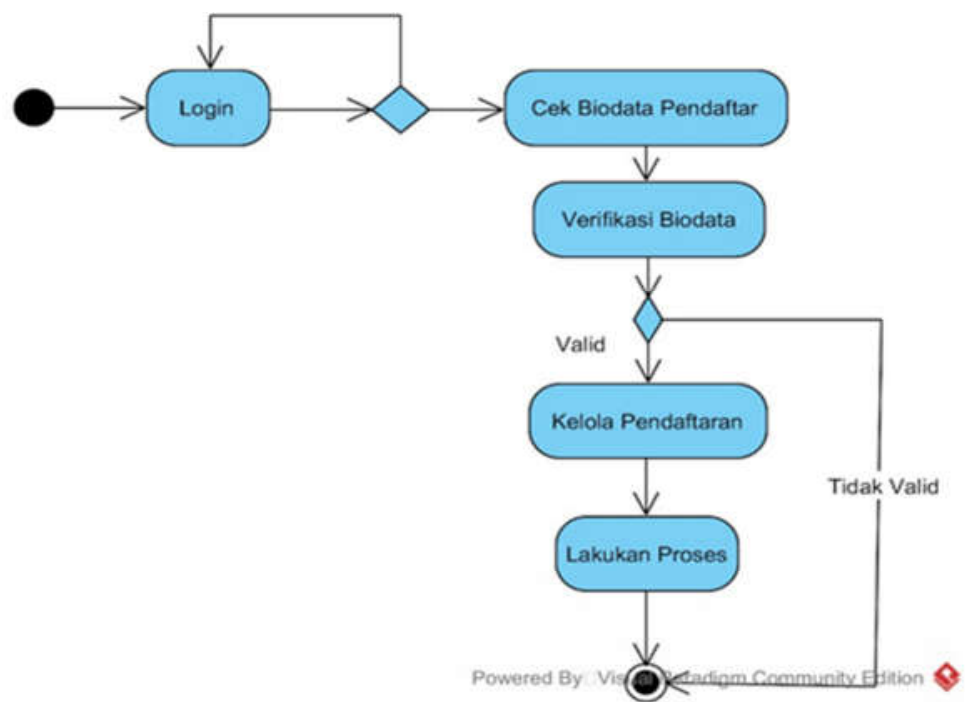

Gambar 2. Activity Diagram Pendaftaran Online

Berdasarkan gambar activity diagram usulan di atas terdapat:

1. 1 Initial Node sebagai awal untuk memulai sistem yang berjalan

2. 2 Decision Node sebagai suatu tindakan apabila terdapat 2 kemungkinan

3. 14 Action State, yang menggambarkan eksekusi kegiatan

4. 1 Activity Final Node untuk mengakhiri sistem yang berjalan

\subsubsection{Class Diagram Pendaftaran Online}

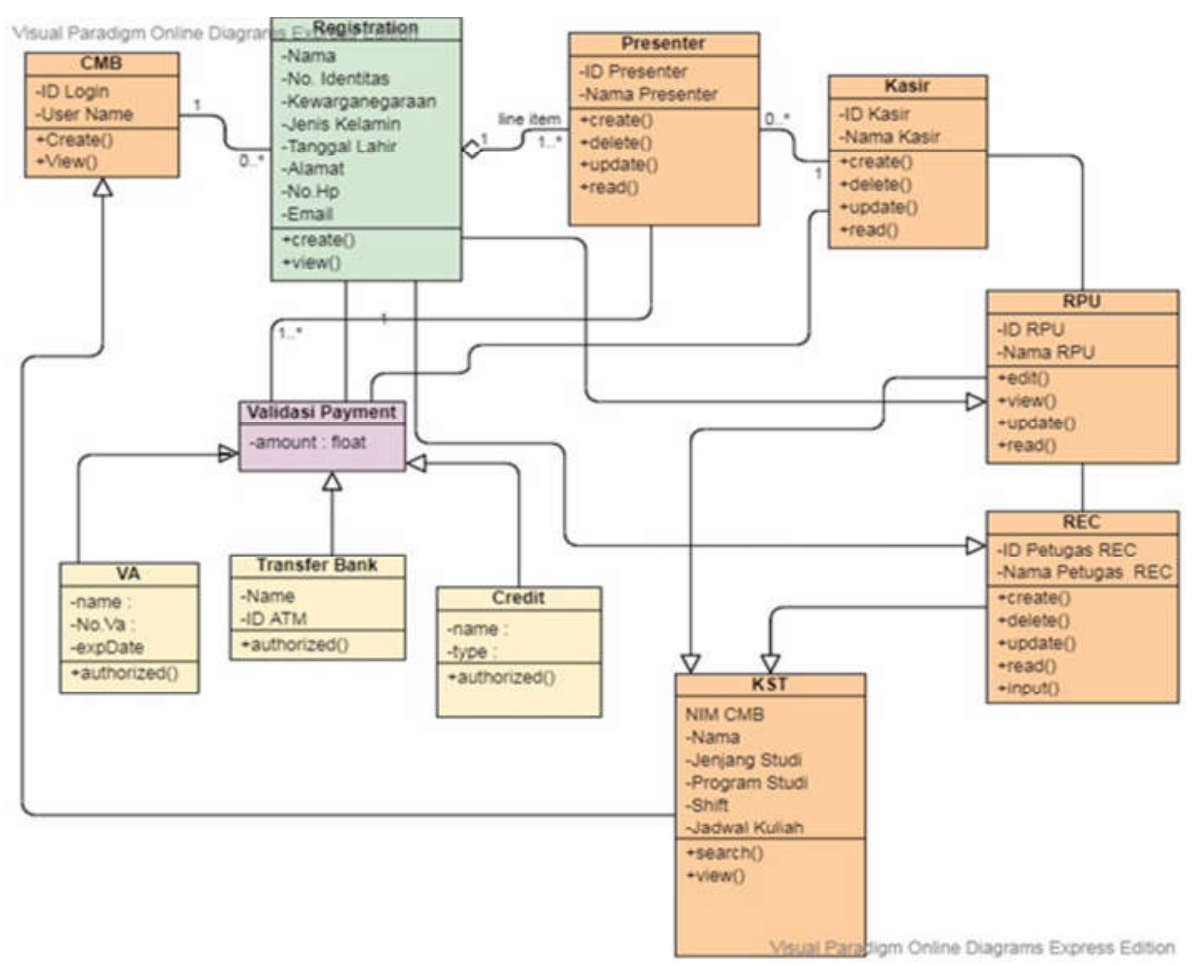

Gambar 3. Class Diagram Pendaftaran Online 
Berdasarkan gambar Class Diagram terdapat:

1. Terdapat 11 Class, himpunan dari objek-objek yang berbagi atribut serta operasi yang sama.

2. Terdapat 16 Association, digunakan untuk memodelkan relasi di antara objek.

\subsection{Implementasi Pendaftaran Online}

1. Tampilan Website
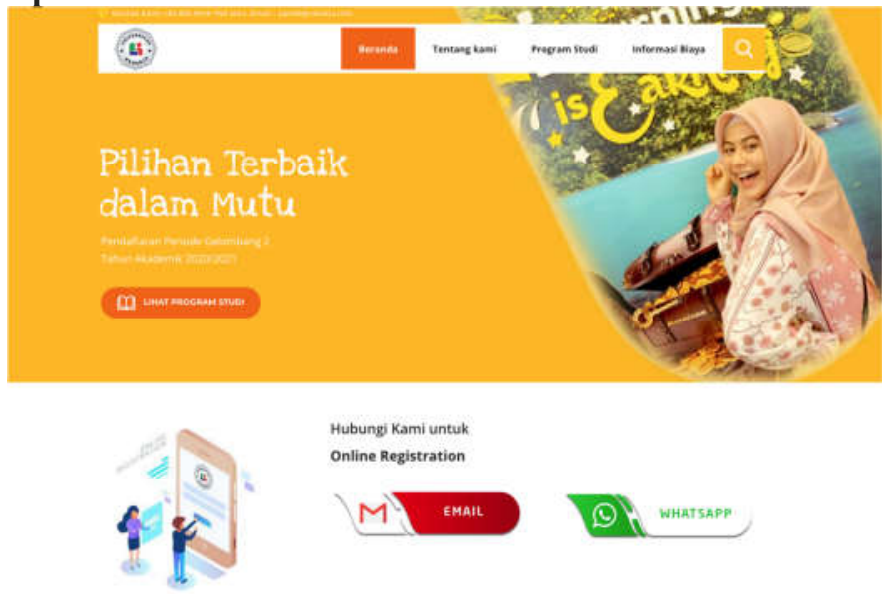

Program Studi

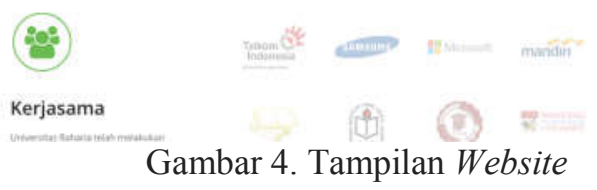

Pada tampilan Beranda website pmb.raharja.ac.id menampilkan banner website, menu-menu, info kontak, dan beberapa logo kerjasama.

\section{Tampilan Menu Pendaftaran}

\section{Daftar Sekarang}
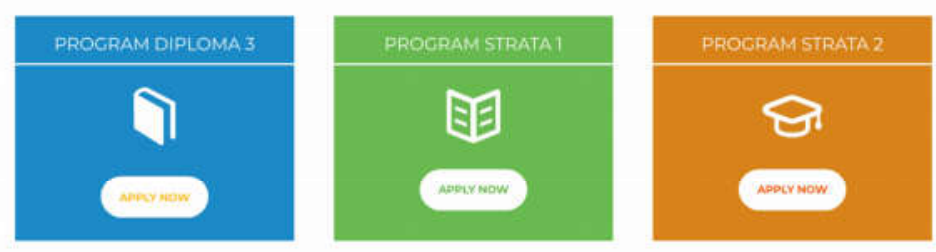

\section{Brosur Universitas Raharja}

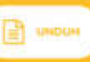

Gambar 5. Tampilan Menu Pendaftaran 
Di tampilan menu pendaftaran menampilkan 3 program yang ada di Universitas Raharja seperti Program Diploma 3, Program Strata 1 dan Program Strata 2 dan mahasiswa bisa langsung download brosur untuk informasi lebih lanjut dengan Program Pendidikan serta fasilitas-fasilitas yang ada di Universitas Raharja.

\section{Tampilan Form Pendaftaran}

\section{Form Pendaftaran Strata 1 Universitas Raharja}

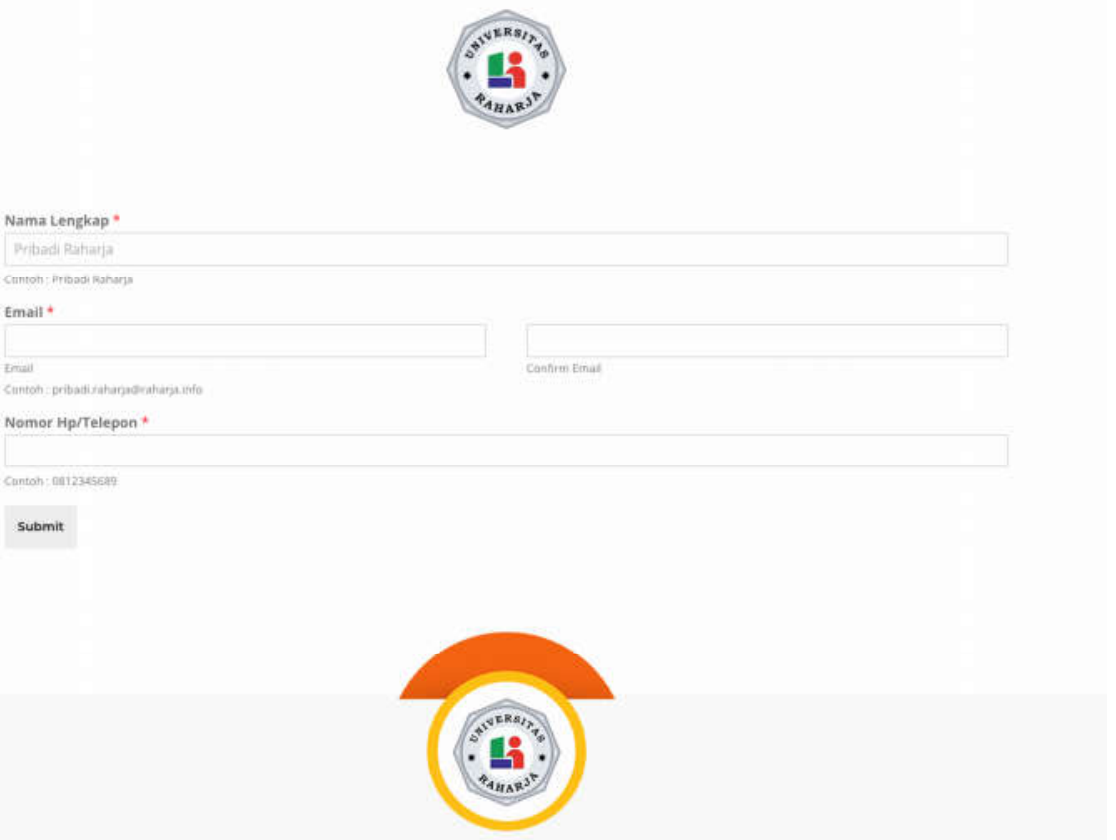

Gambar 6. Tampilan Form Pendaftaran

Pada tampilan form pendaftaran calon mahasiswa baru harus mengisi biodata mereka dengan data yang sebenar-benarnya, seperti : Nama Lengkap, Email, Confirm Email serta Nomor HP/ Telepon yang dapat dihubungi sewaktu-waktu oleh bagian Marketing. Jika semua Data sudah terisi dengan benar lanjut klik Submit.

\section{Tampilan Email Konfirmasi Sukses Pendaftaran}

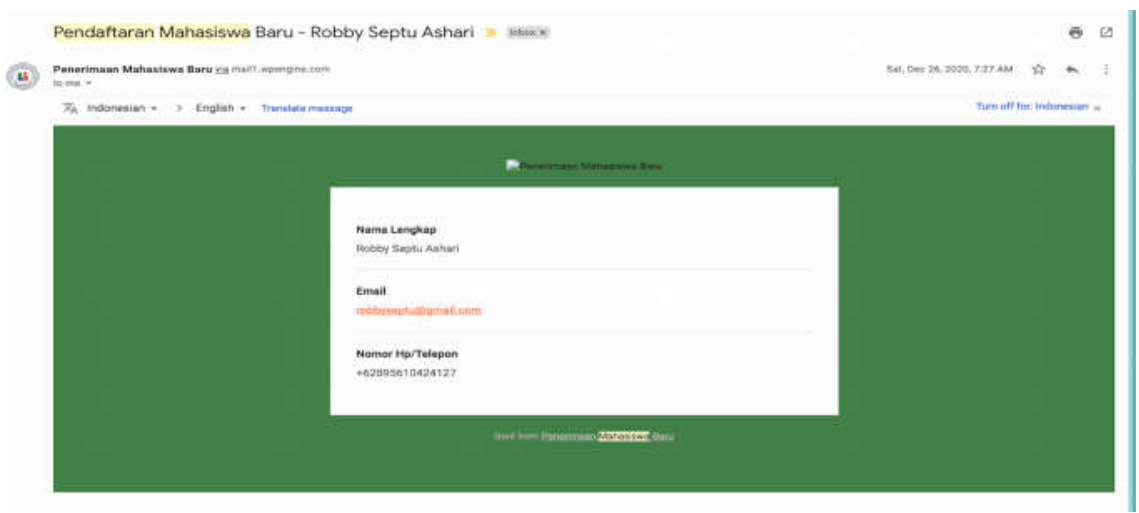

Gambar 7. Tampilan Email Konfirmasi Sukses Pendaftaran 
Setelah mahasiswa telah mengisi data calon mahasiswa baru dengan benar, sistem dengan otomatis mengirimkan email Konfirmasi sukses pendaftaran ke Calon Mahasiswa Baru untuk menyatakan bahwa CMB tersebut telah berhasil melakukan pendaftaran.

\section{Tampilan Database Data Pendaftaran Calon Mahasiswa Baru}

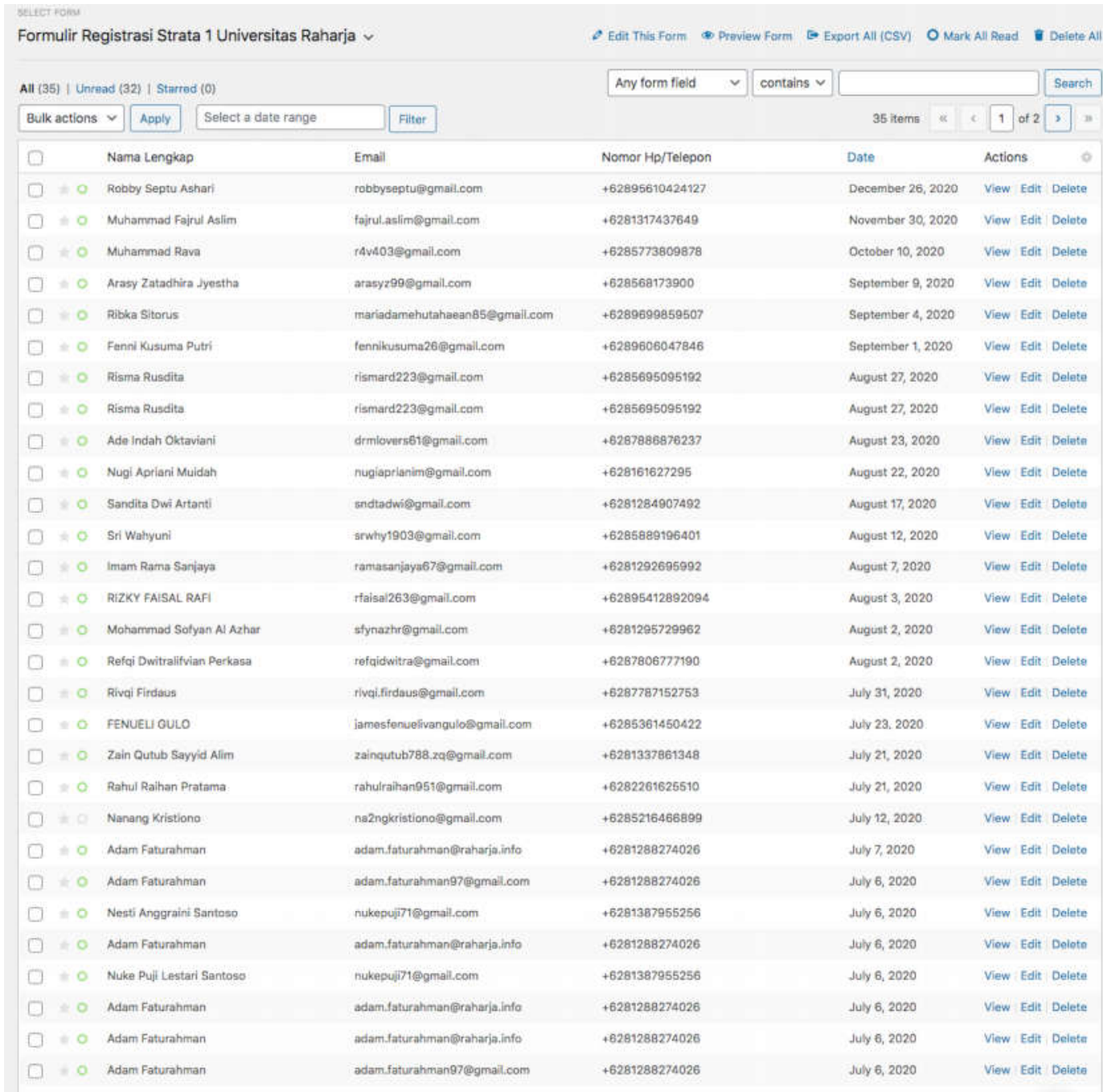

Gambar 8. Tampilan Database Data Pendaftaran Calon Mahasiswa Baru

Berikut tampilan database admin website pmb.raharja.ac.id yang telah melakukan pendaftaran calon mahasiswa baru.

\section{Kesimpulan}

Dengan adanya website pmb.raharja.ac.id sebagai sistem pendaftaran Calon Mahasiswa Baru pada Universitas Raharja secara online ini, maka para Calon Mahasiswa Baru tidak perlu lagi harus menunggu kode akses selama 2x24 jam atau harus datang ke kampus untuk mendaftar secara langsung ke kampus, tetapi dengan hanya menggunakan laptop ataupun handphone sudah bisa melakukan pendaftaran sebagai mahasiswa baru di Universitas Raharja. 


\section{Saran}

Disarankan data dan informasi yang disampaikan di website dapat selalu di up to date untuk memudahkan calon mahasiswa baru untuk mengetahui informasi terbaru yang ada di kampus dan tidak ada terjadinya salah komunikasi atau salah persepsi.

\section{Daftar Pustaka}

Legawa, Samudera Dipa, Ignatius Joko Dewanto dan Henderi, 2017, Merancang Data Mart Perancangan Dashboard Penerimaan Mahasiswa Baru Universitas Muhammadiyah Tangerang, Prosiding Seminar Nasional Multi Disiplin Ilmu Vol. 1, Tangerang : Perguruan Tinggi Raharja.

Muharam, Masyhar dan Andhika Giri Persada, 2020, Implementasi Penggunaan Website Sebagai Media Informasi dan Media Pemasaran Hasil Pertanian dan Peternakan Desa Sumberejo, Prosiding AUTOMATA Vol. 1 No. 2 ISSN: 2721-1940, Yogyakarta : Universitas Islam Indonesia.

Muslih, Muhammad, 2015, Pengembangan E-Marketing Penerimaan Mahasiswa Baru (PMB) Dengan Menggunakan Metode Service Oriented Architecture (SOA) : Studi Kasus Pada STT Nusa Putra Sukabumi, Jurnal Rekayasa Teknologi Nusa Putra, Sukabumi : STT Nusa Putra, http://jurnal.nusaputra.ac.id/ index.html.

Rumondang, Astri, Acai Sudirman, Samsider Sitorus, Aditya Halim Perdana Kusuma, Melda Manuhutu, Andriasan Sudarso, Janner Simarmata, Dian Hasdiana, Tasnim Tasnim, Nina Fapari Arif, 2020, Pemasaran Digital dan Perilaku Konsumen, Medan : Yayasan Kita Menulis.

Suib, Mohammad Syaiful dan Citra Fawaid Rosiana, 2020, Defeminasi Keluarga Pra Sejahtera Melalui Program Kelompok Usaha Bersama (Kube) Berbasis Cyber Marketing (Studi Kasus Pada Desa Bago Kecamatan Besuk Kabupaten Probolinggo), Jurnal QIEMA (Qomaruddin Islamic Economy Magazine) Vol. 6 No. 2 : 134, Gresik : LPPM Islamic Institute Qomaruddin Gresik. 